\title{
Rethinking 'Religious' Cognition: The Eliadean Notion of the Sacred in the Light of the Legacy of Uno Harva ${ }^{1}$
}

\author{
VEIKKO ANTTONEN \\ University of Turku
}

\begin{abstract}
The article discusses methodological similarities and differences between Uno Harva and Mircea Eliade, with the objective of reassessing the value of their comparativist programs for the study of religion in general and of 'religious' cognition in particular. The Finnish scholar Uno Holmberg-Harva (1882-1949) was a predecessor to Eliade as a scholar of Asian and European religious history. During the first three decades of the twentieth century, when the academic study of religion was still maturing in Europe, Harva expanded considerably the field of the ethnological study of religion with his religio-phenomenological monographs Der Baum des Lebens (1922), Finno-Ugric, Siberian Mythology (1927) and Die Religiösen Vorstellungen der Altaischen Völker (1938). Harva was a towering figure in Finnish scholarship. Originally a Protestant theologian and Lutheran minister, he resigned from his ecclesiastical position to become a historian of religion, field ethnographer, ethnosociologist and folklorist under the tutelage of Edward Westermarck and Kaarle Krohn. Harva's influence on the work of Eliade has been almost entirely ignored by historiographers of Religious Studies.
\end{abstract}

Keywords: Mircea Eliade, Uno Harva, Asian cosmology, the sacred, methodology, cognitive theory

\section{Closing the Eliadean Era}

Religious studies has been in the process of closing the Eliadean era for more than three decades. Scholarly development within the field makes the reason look obvious: Eliade's methodology, in which the identity discourse of the discipline - at least in the United States - was anchored, does not belong to science and scholarship in a sense that would grant Religious

${ }^{1}$ This article is based on a paper presented at the panel 'Eliade and His Legacy/Eliade et son héritage' at the annual EASR conference, 'Religious History of Europe and Asia', Bucharest, 20-23 September 2006. 
Studies a respectable, empirically valid and methodologically reliable status in academia. The category of religion is an abstraction of variegated forms of cultural traditions, whether of Western or non-Western origin (see Saler 2000). Nevertheless its academic study constitutes a subject matter which needs to integrate conceptual frameworks and methods of data collection and analysis derived from various academic fields. These include archaeology, history, cultural and social anthropology, sociology, psychology, and today the study of human cognition (see Martin 1996; 2003; Paden 1996). Instead of locating and analyzing religion in the fabric of the social, Eliade placed special emphasis on the authenticity and irreducibility of religious experience. He used his immense erudition in the religious history of humankind as a spiritual leader and a visionary artist more than as an academic scholar. As Terence Thomas has written, 'Eliade proclaimed himself to be a historian of religions and a "scientific" historian of religions at that' (Thomas 2004, 53). Behind Eliade's conception of the wissenschaftlich, however, there lies a hidden agenda. In his four-volume journal (1977-1990), Eliade reveals that in The Patterns of Comparative Religion (1958) his secret message was to disclose the 'theology' in the history of religions. 'So much for being a historian of religions', Thomas points out sarcastically (Thomas 2004, 54).

One of the most active opponents to Eliadean approach to religion, Russell McCutcheon wrote recently that after Eliade the field needs to be retooled from top to bottom (McCutcheon 2003, 209). For scholars in a modern research university, the Eliadean type of study of religion is hopelessly imprecise and subjectively weltanschaulich. In keeping the history of religions intact from the social sciences, the study of religion cannot address the pressing issues of the role played by religion in the present-day global world, or even - as R. J. Zvi Werblowsky has pointed out - account for the role of religion in history, since Eliade's concept of history is problematic and paradoxical in its ahistorical emphasis (see Werblowsky 1989, 130).

Regarding the relocation of Eliade within the scholarly history of the study of religion, the present situation is in my view a happy one. We do not need to purge Eliade from our disciplinary horizon. Eliade and his era can be released for the historiographical analysis of the history of religion's history (see Smith 2004). Eliade is bound to pop up in future scholarship in connection with the key concept of his research: the notion of the sacred and the linkage of its mythical contents to notions of spatiality, territoriality and corporeality in cultural traditions the world over. Putting aside Eliade's evaluative remarks on the a priori nature of religious ontology, there are theoretical implications in the Eliadean methodology that need to be ad- 
dressed in reconsidering the role played by socio-spatial categories and the marking of their boundaries in the making of religion and ritual in global as well as local secular contexts (see e.g., Moore 1984; Smith 1987; Parkin 1991; Paden 1992; Anttonen 1996a; 1996b; Knott 2005; Colpe 2005).

In this article, my purpose is not to go 'beyond Eliade' (see Rennie and Laitila in this issue) and repeat what has been said of him as a scholar and his impact on the scope, content and goals of the study of religion as well as its public image among non-specialists. Rather, I shall open up a link to Eliade which has previously been less familiar in the scholarly history of the discipline. By focusing on the work of the Finnish scholar Uno (Holmberg) Harva, I shall shed light on certain shadowy areas of European scholarship before Eliade which have been inadequately explored so far. I do not mean to say that Finnish scholarship has stood in the shadow due to the geopolitics of the European study of religion. On the contrary: ever since the formative years of the discipline of Religionswissenschaft in Europe, Finnish scholars - Uno Harva ${ }^{2}$ among them - have made significant contributions to the accumulation of knowledge and ideas. My choice of focus is a methodological one; it starts from the need to find areas where previous research has cast inadequate light. Too frequently the sources provided by established academic ancestors and institutions rule the methodology by which the historiographic work is carried out and the resulting master narratives are constructed (see Sharpe 1994; Capps 1995). By this choice, I am placing these two men - Uno Harva, professor at the University of Turku and Mircea Eliade, professor at the University of Chicago, on an equal footing and recontextualizing them as European exponents of the history of religions in general and as scholars of European and Asian religious history in particular. The theories of both Harva and Eliade, like theories in general, reflect the normative structure of specific scholarly communities and as such are contingent on specific historical, religious, political and other ideological factors prevalent in the intellectual milieu in which they worked. As a predecessor to Eliade, Uno Harva exercised a direct influence on him. To my knowledge, however, the only personal link between Harva and Eliade involved the latter's extensive references to the scholarly work

\footnotetext{
${ }^{2}$ I am referring to the work by Edward Westermarck and his disciples, who explored the origins of religious ideas: the scholar of the South-American Indians Rafael Karsten, who wrote his doctoral dissertation on the origin of priesthood, and Gunnar Landtman, who carried out extensive fieldwork among the Kiwai Papuans in the New Guinea and explored the origins of social inequality. Uno Harva became a specialist in Finno-Ugric and Siberian ethnography. Harva finnicized his last name Holmberg in 1927.
} 
of the former, and the fact that Eliade attended the IAHR conference on methodology that the Finnish scholar Lauri Honko organized on Harva's home ground at the University of Turku in 1973. Uno Harva had already passed away in 1949.

\section{The Academic Profile of Uno Harva}

As scholars of the religious history of Europe and Asia, both Uno Harva and Mircea Eliade adopted a definition of religion which was more mythological than theological. This allowed them to systematize diverse literary and oral tradition sources. Anchoring themselves on the scholarly traditions of the history of religions and becoming familiar with the sources of premodern forms of religious worldviews among European and non-European peoples, the perspective of both Harva and Eliade was significantly extended beyond the conventional understanding of the notion of religion. Both of them placed their focus on non-organizational, diffuse folk beliefs and practices, so as to avoid postulating Christianity as the prototype of the category of religion. Uno Harva was the son of an Evangelical minister who held an important position in one of the Protestant revivalist movements in southwestern Finland in the first half of the twentieth century. Harva himself was first trained as a Protestant theologian at the Faculty of Theology at the Imperial Alexander University in Helsinki (Finland was a Grand Duchy of Russia until December 6, 1917). He served for one year as minister in a small parish in Kuorevesi, Central Finland, but resigned from the office in 1907 due to the shaking of his religious conviction. Harva returned to Helsinki and became a disciple of two distinguished professors in their fields, the folklorist Kaarle Krohn and the the social anthropologist Edward Westermarck. Westermarck had gained international recognition and held a position at the London School of Economics, where Bronislaw Malinowski became one of his students. Westermarck, whose professorship in Finland was in Practical Philosophy, was a cultural relativist and empiricist who actively participated in the discussion in the Finnish public sphere of the role of the Evangelical-Lutheran Church as a State Church, promoting secularism and ethical relativism. Kaarle Krohn, Professor of Folkloristics at the University of Helsinki, was in contrast a devout Christian, who developed further the geographic-historical method in Folklore studies - known as the Finnish method - that had been initiated by his father Julius Krohn.

Uno Harva adopted Westermarckian empiricism and comparativism as well as the urge to obtain first-hand ethnographic data on indigenous religious traditions among the Finno-Ugric peoples. Harva's direction as 
a scholar took shape during the first decade of the 1900s: he set off to do fieldwork among the Udmurt and Mari in Eastern Russia, in order to unravel the origins and development of religion among peoples speaking FinnoUgric languages. As was implicit in the Finnish method, Harva aim was to unravel the evolutionary scheme of folk-religious beliefs and practices by tracing the primordial layers of variegated forms of ritual tradition within distinct nations and peoples among the Finno-Ugric language family. Harva hypothesized that the religious representations that still prevailed among technologically and socio-economically 'less developed' Finno-Ugric peoples living in Russia and Siberia could shed light on the early stages of religion among the more developed nations, Finland, Hungary and Estonia. Harva adhered to the comparative-typological method, by which he could explore the forms and structures of mythical narratives and ritual expressions and draw inferences as to continuities and changes in cosmology and religion as the culture in question moved from the stage of a hunting and fishing economy to the agricultural stage. In the conceptual framework adopted by Harva, there was no need to draw a sharp distinction between the notions of religion and tradition. According to him, any popular, i.e., non-theological religion is based on the oral transmission of local knowledge revolving around ritual interaction between people and invisible terrestrial and celestial forces. Certain components are integral to any indigenous religious tradition; these include beliefs in gods and souls, veneration of dead ancestors, the animation and anthropomorphization of natural phenomena (the genius loci of sacred places in inhabited and uninhabited areas), and cults of mythical heroes. Harva's main explanatory issue revolved around the role that the major superhuman entities - the dead, nature spirits, and the sky god - played in folk life in establishing, maintaining and renewing the social order.

As a result of his ethnographic fieldwork, Harva created a distinctive way of systematizing ethnomythological materials. He identified in the traditional religions of Finno-Ugric, Siberian and Central Asian peoples a fundamental structure of the world, the center of which revolved around the notion of the world-pillar or its functional alternatives, the world tree and the cosmic mountain, and their mythical representations in the shaman's tree, temples, towers, pagodas and minarets (Holmberg 1922, 45-51). Being a rationalist (see Anttonen 2005b, 3782-3784), Harva adopted the term worldview to refer to the cognitive organization of mythological ideas as they were represented in architecture as well as in literary and oral tradition sources. He used religion as a comprehensive label to refer to representa- 
tions of cosmography in mythical narratives and in various forms of ritual behavior. In his book Finno-Ugric and Siberian Mythology, Harva wrote:

In looking at the sky, the attention of people was drawn to a certain fixed point, round which the heavens, as seen from the earth, seemed to revolve. This regular motion of the sky, which is as we know to be due to the movement of the earth round its axis in the opposite direction, awakened among primitive peoples the idea that the sky at this point, i.e., at the North Star, is affixed to some object bearing or supporting the heavens. (Holmberg 1927, 221.)

Referring to the traditional Eurasian cosmology, Harva posits that ' $[a]$ more suitable throne in the sky than the stationary, changeless region of the skynavel near North Star, whence he can best direct the countless, varying activities of the earth, can hardly be imagined for the Supreme God' (Holmberg 1964, 401). In spite of his use of the masculine third-person form, at the center of Harva's representation of Central Asian cosmology was the Mother Goddess, the female ruler who was depicted in myths sitting beneath the tree of life at the paradisical center of the world (see Holmberg 1922, 83ff). Harva's groundbreaking phenomenological studies on the mythical worldview led him to set place the enigma of the Sampo in the Finnish national epic Kalevala in this Asian-based mythopoetic frame of reference. Emphasizing the ritual aspect, Harva had posited that the Sampo, forged by the mythical culture hero Ilmarinen at the time of the creation of the world, was a man-made replica of the mythical world pillar, represented in a sacrificial context in a community cult. This supposition was based on the evidence of shamanistic practices not only among the peoples of Northern Eurasia but also among the ancient Germanic and Saami tribes. According to Harva, the Sampo and the kirjokansi, 'the bright lid of the heavens', do not refer to the myth of the Grotti mill in Germanic epic poetry, but are images which formed part of the worldview of the ancestors of the Finns. 'What else could the sammas or Sampo mean, in referring to a pillar, than the supporter of the heavens, the so-called world pillar', Harva wrote. As he saw it, prehistoric peoples needed the symbolic representation of the mythical world pillar, supporting the heavens by the North Star, to promote a good harvest and general fertility. (See Harva 1944, 339; Anttonen 1987, 138-141; Anttonen 2000c, 166-167.)

\footnotetext{
${ }^{3}$ The Aryan/Iranian origin of sammas < *stamhas 'pillar', 'stanchion' belongs to the same linguistic strata as the words for 'god' and for 'heaven'. The Finnish word jumala, 'god', belongs to the western group of Aryan loanwords; jumala is derived from the Proto-Iranian noun dyumna- and the adjective *dyumān 'heavenly', 'clear', 'shining'. See Anttonen 2000c.
} 
In his analysis of world-pillar myths, Ake Hultkrantz accepts Harva's bipartite theory. Hultkrantz distinguishes in the motif of world pillar a cosmological level and a ritual level. The pillar motif is represented in myths and beliefs as the sacred center of the world, the function of which is to support the sky. In ritual, the pillar is represented in a replica such as a pole or alternatively a tree, a house or a temple, around which the socio-religious life of the community revolves. According to Hultkrantz, the pillar motif 'stands out as the central symbol in a cosmological structure that marks the Universe both as space and as time; it symbolizes the beginning of the world and, if it falls, the world will end' (Hultkrantz 1996, 36-43.).

Prior to the functionalist turn in the study of culture, Uno Harva developed a homespun functionalism which allowed him to integrate ethnographic data into the morphology of social life. From the very start of his career as a scholar of religion Harva was inclined to view religion more in terms of a property of social collectivity than as an individual predisposition to the realm of transcendence. Harva had carried out extensive ethnographic fieldwork among the Udmurt and Mari in Eastern Russia in 1911 and 1913 and among the Kets (Yenisej-Ostyaks) and Evenks (Tungus) in Siberia in 1917. The bulk of his argumentation centered on the contribution of types of belief and ritual practice to the social order. Harva repeatedly emphasized the importance of lineage categories for the organization of sacrificial rituals and memorial observances for ancestors. Among the Udmurt, the kin classification was maintained by rules of exclusion of members of other lineage groups from ritual gatherings. Ritual form and the subsequent taboo norms were major social mechanisms by which lineage boundaries, and the social order, were kept intact. Bronislaw Malinowski, who reviewed Harva's book Finno-Ugric and Siberian Mythology, gives Harva credit for his account of the role of myth in society. Malinowski wrote that Harva's book was one of the best descriptions of the primitive Weltanschauung and one of the most important additions to the science of myth (Malinowski 1962, 294). 'The insistence with which the real nature of myth and legend as the traditional precedent of belief, moral rule, and social organization is brought out in this volume is the natural outcome of a thorough knowledge of the material. This is the more convincing since the Finnish author does not seem to be aware of its theoretical importance.' (Malinowski 1962, 293.) In reference to shamanism, Harva displayed a linkage between the totemistic social system and the inheritance of supernatural powers through the shamanic lineage. Both totemistic and shamanistic types of belief are rooted in mythological ideas centering on the role of animals as mediators of power to ancestors of the shamanic kin. 


\section{Shamanism and the Archaic Worldview in Europe}

In the introduction to his work on shamanism, Eliade credits Harva as one of the few notable exceptions among scholars of religion who have interpreted the complex phenomenon of shamanism in the framework of the history of religions. As indicated above, the framework created by Harva after his fieldwork in Siberia in 1917 in order to explore the motifs and symbolic structures displayed in mythical narratives and rituals of Siberian shamans precedes those formulated by Eliade. However, there are also marked differences. As his references indicate, Eliade employed ethnographic data collected and published by Harva in Der Baum des Leberns (1922) and in Die Religiösen Vorstellungen der altaischen Völker (1938). In his treatise on Shamanism: Archaic Techniques of Ecstacy (1964) Eliade addressed the ethnoreligious data of Harva according to his own interpretative vision and evaluative vocabulary. In explicating the grounds of belief in guardian spirits and mythical animal helpers, Eliade remarked that these are not exclusively characteristics of shamanism. Rather than validating his 'method' of phenomenological reduction by comparative ethnographic data on recurrent features in shamanic systems of belief and practice, he argued that 'they are collected almost anywhere in the entire cosmos, and they are accessible to any individual who is willing to undergo certain ordeals to obtain them [...] everywhere in the cosmos archaic man recognizes a source of the magico-religious sacred, that any fragment of the cosmos can give rise to hierophany, in accordance with the dialectic of the sacred' (Eliade 1964, 107).

Being an empiricist and comparativist, Uno Harva would have found Eliade's shift in the level of analysis obscure and unjustified with regard to ethnographic data and the task of comparison. In reference to his findings of the mythical organization of the structures of belief and ritual practice, Harva would have understood what Eliade meant by the symbolism of the sacred, since he identified recurrent motifs in myths and rituals and explored their cultural variation. However, it would have been out of question for Harva to replace social analysis by an act of phenomenological reduction and to claim that regardless of the social and historical context and differences in individual worldviews, these representations (in Eliade's terms hierophanies) are manifestations of a panhuman religious ontology. Both Harva and Eliade shared an interest in the evolution of religion, but they drew opposite conclusions as to the level of discourse at which mechanisms of distinct evolutionary stages are identified. Harva held the conviction, similar to that of Émile Durkheim, that the study of myths and rituals of small-scale societies can shed light on the patterns of organization of human society in 
early stages of history, since most human institutions have religious, i.e., mythical origins. This view has motivated the methodological shift among scholars of religion to extend the area of validity of theories of religion and to locate the 'religious' within the secular.

\section{The Sacred as The Hallmark of Religion and The Object of Religious Studies}

Eliade held the hallmark of religion to be the notion of the sacred (or the holy). The sacred was the very essence from which an understanding of religious worldviews in the course of human history departed. Eliade abstracted the notion of hierophany to denote a special property in human beings to perceive and decipher qualities and modalities of sacredness in persons, objects, times and places. Hierophanies were manifestations of a panhuman religious ontology. The abstract, ontologically a priori idea of the sacred is not always theologically or mythologically given according to its various forms of schematization (a term coined by Rudolf Otto) in specific religious or cultural traditions. For Eliade, the idea of the sacred represented an existentially true form of reality, an ontological level of existence which manifests itself to religious persons, i.e., to homo religiosus. Eliade considered the sacred as a dynamic force that is manifested on the social level of spatial and corporeal divisions, where religious persons can share in the force, hold communion with the sacred regardless of the historical and geographical context (Eliade 1958, 367-369).

For Eliade, the religious person par excellence was not a Jew, a Christian, a Muslim or a Buddhist, but an archaic man or any individual for whom the hierophanies manifest themselves and open up. Homo religiosus, the religious individual that Eliade envisioned, was, however, not a gendered individual, an actual person with a distinctive history and cultural heritage, but a paradigmatic individual. According to Eliade, the human capacity for 'religion' could not be reduced to his or her membership and identity formation in a specific, historically constituted society. In the Eliadean study of religion, the process of deciphering or reading the manifestations of the sacred in the midst of social life is not an intellectual activity but a psycho-mental process, in which the religious person returns to the mythical 'beginnings' (Eliade $1975,172)$. Religion arises from the human capacity 'to telescope all events in the same atemporal horizon of the mythical beginnings' (Eliade 1975, xii). Regardless of the historical and geographical context, Eliade abstracted religiosity as a special atemporal property in human beings. It is this qual- 
ity that makes religious people competent to perceive 'archaic elements of culture' and decipher them on the basis of models and paradigms provided by religious documents. Eliade argued for the importance of the study of European folk cultures, in which 'peasants', by adhering to their ancient inheritances, have escaped from the terror of history by means of archetypes and symbols. A historian of religion does not need 'to confine himself to the historical forms of Christianity, since popular Christianity still retains a cosmic structure that has been almost entirely lost in the experience of urban Christians' (Eliade 1959, 164). While theorizing that the 'sacred' is an element of consciousness, not a stage in the history of consciousness (Eliade 1969), Eliade in fact demarcated the issue of sacrality in a valid scholarly manner. Holding to Eliade's argument that there is a transconscious level at which human 'religious' cognition works, questions could be posed as to the specific properties of human cognition and the way these evolved mental dispositions constrain the formation of religious ideas in general and the attribution of sacrality to categories of things, persons, times and places in the external world in particular. However, due much to the impact of depth psychology as well as to a general lack of scientific interest, Eliade was more inclined to religionize human mental faculties than to provide scholarly tools for their systematic exploration. The postulate that beyond historically contingent hierophanies there exists a non-dependent and eternal deep structure, the sacred, provided him with his main platform for the organization and analysis of its morphology. Eliade assessed the value of both religious documents and ethnographic accounts by field anthropologists according to their ability to display archaic mythico-ritual scenarios inherent in the data. In the autobiographical fragment written by Eliade in Paris on March 24, 1953, he states that

I have never felt myself capable of composing a 'purely scientific' work of ethnography or folklore. I am interested only in the spiritual documents which lie buried in those reams of books published by ethnographers, folklorists, and sociologists. In those hundreds of thousands of pages I believe there survives a world of myths and symbols which must be known and understood, if we are to be able to understand the situation of man in the Cosmos. (Eliade 1982, 114.)

\section{Whither the Study of 'Religious' Cognition?}

Eliade departed from the view that no clear line needs to be drawn between religion and non-religion. The domain of the religious was not confined to 
religious traditions per se, but extends into the domain of the secular as well. Regardless of the fact that Eliade lacked scientific interest, he shared this attempt with present-day scholars of social-scientific and cognitive orientations. Although gods, spirits and other superhuman agents are used as context markers whereby religion is set apart from non-religion in specific social situations, there are 'religious' or 'sacred' elements and discourses beyond the domain of religion, which deserve to be looked at not only in order to understand and explain cultural phenomena themselves but also for methodological reasons, so as to develop new interpretive and explanatory strategies for the study of religion. In addition to social-scientific and phenomenological reduction, present-day representatives of the cognitive science of religion have introduced a new level of reduction to theorize religion. In Faces in the Clouds (1995), the anthropologist Stewart Guthrie argues for a new, intellectualist theory of religion. Guthrie posits that the human propensity to religion can be explained by a perceptual strategy common to humans and primates, in which characteristics of living things (e.g., sentience and spontaneous motion) are attributed to inanimate things and events. According to Guthrie, animism (making alive) and anthropomorphism (making human) are the paramount cognitive properties in terms of which recurrent features in religious representations in cultures the world over can be explained. By a 'tendency to anthropomorphize' Guthrie is referring to the attribution to non-human things, objects, events and animals of human mental capacities such as linguistic and symbolic communication skills (see Guthrie 1995, 197-204). Biological evolution has equipped human beings with a special kind of mental architecture that constrains the formation of religious ideas. Guthrie argues that the human mind is hard-wired to detect humanlike agents.

The French anthropologist Pascal Boyer, on the other hand, points out another new explanatory avenue for approaching the conceptual domain of religion in his book The Naturalness of Religious Ideas (1994) as well as in his follow-up book Religion Explained (2001). While Guthrie considers agency detection an intuitive property of humans, Boyer focuses his attention on recurrent features in religious representations which run counter to our intuitive assumptions (Boyer 2001, 65, 73). Drawing on the work of cognitive psychologists on ontological distinctions, Boyer introduces the notion of 'counter-intuitiveness' as a technical term to refer to the class of phenomena that contradict some of the information provided by intuitive ontological categories. He refers to the massive amounts of evidence of counter-intuitive representations in the world's mythologies, fantastic tales, 
anecdotes, cartoons, religion and science fiction. The dominant characteristic in genre-specific representations of gods, humans and animals, as well as invisible, humanlike agents such as ghosts, is their counter-intuitiveness: super-human agents violate the physical, biological and psychological properties which we humans intuitively ascribe to ourselves as bodily persons. Gods, for instance, are thought to possess a humanlike mind, but they are not constrained by other biological, physical, physiological or psychological properties peculiar to ordinary human beings. Gods are offered food in sacrificial rituals; yet they do not grow, get old or die. Dead beings or ghosts, on the other hand, are not bothered by solid objects (Boyer 1994, 100-102). Once we have ontological categories of persons, plants, animals and artifacts, along with a set of assumptions and inferences as to the properties according to which members in specific ontological categories are expected to behave, the human mind is capable of making up hybrid forms of combinations in which these ontological assumptions and expectations are violated (Boyer 2001, 63-71). Boyer coined the term 'cognitive optimum' to explain why certain kinds of religious or magical ideas are successful in transmission. For cognitively optimum ideas to transmit, they need to show both intuitive, i.e. prototypical properties and counter-intuitive, i.e. non-prototypical ones in a certain balance (Boyer 1994; 2001).

Do these approaches have any bearings on rereading Eliade's work on the phenomenology of religion? In paying attention to cognitive aspects of religious symbolism in the ethnographic data on shamanism, we are better prepared to understand for instance the behavior of Siberian and Saami shamans, who are reported to have the ability to fly, to occupy two separate and far distant spaces simultaneously, to enter the abode of the dead in the underworld, or to metamorphose themselves into wolves; in other words, to employ the innate human capacity for cognitively optimum religious representations. While it is intuitive to attribute humanlike properties to stones, rocks, rivers or mountains, or to the shaman drum, as a bodily person with 'ears', 'lungs' and 'artery', it is counter-intuitive to believe that these objects and artefacts have the same biological, psychological and physiological properties as human beings and are capable of performing similar kind of intentional actions. Intuitiveness and counter-intuitiveness are both natural properties of human beings. As cognitive agents, humans are predisposed to the conceptual organization not only of sights, sounds, smells, tastes, objects, events, but also of notions of unseen agents and entities; and, moreover, of the properties of things and objects on the basis of which they are set apart from other similar things and objects. Whether these abstractions are labeled 
religious, sacred, or merely in some way different, they are nevertheless integral characteristics of the way human cognition works.

\section{Placing the Eliadean Notion of the 'Sacred' in a Cognitive Framework}

The Eliadean notion of the 'sacred' has had a strong public appeal for nonacademic readers of scholarly literature. His books on the religious history of humankind have perhaps functioned as accounts by a prophet who has seen and experienced 'how the sacred works' in the mind of a religious person. From the scholarly point of view, however, the Eliadean notion of the sacred does not provide a tool for academic scholars of religion analyzing religious and cultural materials, whether as historians, anthropologists, sociologists or folklorists. In my own theorizing of the concept, I have construed a category-theoretical approach to religion (see Anttonen 1996a, 1996b; 1999; 2000a; 2000b; 2002; 2004; 2005a), in which special emphasis is laid on ethnographically observable, behaviorally constituted cultural and mental representations. The conceptual-semantic approach aims at explaining why vernacular terms denoting the 'sacred' exist in the first place and how similarities and differences in their use and meanings in the course of history in different geographical circumstances can be approached and theorized. In paying closer attention to the mechanisms whereby expressions of sacrality are constituted in human thinking and behavior, and how their set-apartness and/or opposition to non-sacred activities is construed, we encounter one of the major scholarly issues in the comparative study of ideas and phenomena generally subsumed in the conceptual domains of 'culture', 'religion', 'ritual' and 'mythology'. In this analysis, we do not have a ready-made conceptual framework at our disposal. My approach is in tune with - and to a certain extent influenced by - the work of Jonathan Z. Smith and William E. Paden (see Smith 1987; 2004; Paden 1991; 1992; $1994 ; 1999 ; 2000)$. The setting apart and demarcating of something as sacred, e.g., for ritual purposes, is a universally recurrent feature in human cultural thought. Rather than paying attention only to theological, philosophical and metaphysical levels of conceptualization, my non-Eliadean point of departure lies in the semantic analysis of terms denoting the sacred in the vernacular, in the very contexts where they are used. The theory is designed to explore how people construe and maintain the fundamental cultural values of their membership communities by marking off and ritualizing category boundaries in various value-laden social situations. In analysing linguistic and ethnographic data, notions of margin, boundary, crossing- 
point and categorical anomaly are irreplaceable sources of information in the attempt to capture the constitutive factors on which the conceptual foundation of religion - as an analytical category - rests.

The 'sacred' itself is a category the members of which are all things set apart, i.e. the specific, value-laden members in the categories of things, objects, times, places, persons, animals and other visible or invisible agents, the special position of which are marked by behavioral rules and restrictions. Regardless of its polysemy, the words and concepts denoting the 'sacred' form an important arena for scrutiny in the study of history, language, culture, religion and human cognition. For the very reason that these fundamental scientific questions are lacking in Eliadean study, his notion of the existential sacred is non-applicable in empirical scholarship.

\section{Towards a Socio-cognitively Grounded Theory of the 'Sacred'}

As Russell McCutcheon has stated, the Eliadean era can be closed with dignity (McCutcheon 2003, 191). My personal participation in the Eliade affair is both historiographically and methodologically motivated. In assessing the work of Eliade in the light of the legacy of Uno Harva, my purpose has been to reconstitute the notion of the 'sacred' as a scholarly category in the study of religion to build an empirically tractable tool. Social-anthropological and cognitive theorizing provides an important additional avenue as a means to this end. Even if some mental properties are fundamental in the making of 'religion', there exists no a priori religious cognition as such. Religiosity is a matter of establishing a relation between specific concepts and their referents in specific power- and value-laden sociocultural contexts. The socio-cognitive reformulation of the 'sacred' as a marker of category boundaries may have more analytical value in conceptualizing religion than previously assumed by theorists of religion. The theoretical import of the notion does not lie in the persistence of its use, in the persistence of specific tradition-bound discursive practices, religious or non-religious, but in the persistence of the human obsession with investing the boundary points of categories with a special referential value and inferential potential (see Anttonen 2002, 30-31). It is not the terms 'sacred' or 'taboo' that matter, but what we learn by exploring their use in different historical times and in different geographical locations. This second-order learning is a cognitive enterprise, even if no exact cognitive mechanism can be identified which determines this human obsession with the marking off and setting apart of category boundaries and the establishing of forms of ritual behavior in connection with their transcendence/transgression. On the other hand, ver- 
nacular terms denoting the 'sacred' in various languages and their development into religious concepts are indicative of the persistence of the 'sacred' from prehistory up to the present time. It is my conviction that explaining the semantic contents of these terms and their integration into the fabric of social life is a major research tool, a means to an understanding of religion as an analytical category. In this enterprise, social-anthropological and cognitive approaches can join forces and proceed from the propositions made by preceding scholars in which scholarly notions of religion and ritual are viewed against the human tendency to establish and perpetuate a sense of order (see e.g., Rappaport 1999). One major way of making distinctions involves different representations of the division between the internal and the external, the visible and the invisible in reference to human society, territory and the corporeality of its individual members. Human beings have a natural propensity to fabricate various forms of sacralities by cutting off, setting apart, purifying and making whole (see Choksy 2003) in order to survive, prosper and grow; in brief, a propensity to establish, maintain and transform their systems of value. In both human and in religious history, territoriality and corporeality have provided the major platforms for making value-laden divisions visible in social behaviour. In any social system, the interplay between the internal and the external is a salient feature. In my theory of the 'sacred' I postulate that the use of vernacular terms denoting the 'sacred' have become actualized at the intersection of the boundary lines separating and connecting the internal and external of the human body and the territory. The outside of the human body is co-terminous with the inside of the territory; they are both stages for value representation and production both in the flow of everyday social life and in ritual context. The inside of the human body is co-terminous with the outside of the territory: they both provide a means for maintaining the integrity and the validity of specific cultural forms over major transitions and transformations, such as death. (Anttonen 1996a; 1996b.) The persistence with which various systems of boundary-transcendence and boundary-maintenance are observed, controlled and ritually enacted in social life lays bare the thinking which has contributed to the viability of the notion through historical stages. In their comparative projects, Uno Harva and Mircea Eliade aimed at interpreting historical documents by focusing their attention on myth and ritual, as notions that would allow them to conceptualize the fundamental cultural structures that generate religion and religiosity. There is much to learn from their methodologies, even though today we have much more subtle conceptual tools at our disposal for the analysis of historical forms of religion and 
their culture-specific constitution. An analytic focus in the study of religion cannot be confined merely to the conceptual domain of explicitly religious systems, whether experiential, vernacular or doctrinally organized. The area of expertise of a scholar of religion needs to be extended to the semantic study of words and their use in common parlance, in reference for instance to place-names: to specific sites in local topography, in narrative genres of oral tradition and in theological literature. Whether we are dealing with conceptual linkages between the notions of 'territory', 'border' and the 'sacred' among premodern, modern or postmodern peoples, we need to remember a simple fact: spaces and territories do not have much significance for humans unless they are differentiated from other spaces and territories. As the anthropologist David Parkin $(1991,3)$ has pointed out, 'people only identify areas in relation to other areas'. The notion of a boundary - and subsequently the image-schematic distinction between the 'interior' and the 'exterior' of a territory - is an integral element in this identification. The notion of sacrality is a relational category that becomes visible in beliefs and practices in which value-laden distinctions are negotiated between subject positions of cultural agents in relation to powers and dangers connected with specific spaces and objects, whether visible or invisible, in the interior and the exterior. The notion of boundary becomes important in these beliefs and practices; it is not materialized merely in concrete fences or walls erected between territories, as in the case of the West Bank between Israel and Palestine. The qualitative difference of a site, location or behaviorally constituted moral institution may also be marked off by invisible boundaries, as in the case of setting heterosexual marriages apart as 'sacred' in relation to the 'sacrilegious' marriages of persons of same sex.

As an open-category approach to religion, the theory of the 'sacred' as a category-boundary has advantages over closed definitions of religion (see Comstock 1984). The analytical focus in the study of religion cannot be confined merely to the conceptual domain of explicitly religious systems, whether vernacular or doctrinal. In focusing on the semantic contents of the local use of linguistic categories, scholars of religion are better prepared to explore the conceptual foundation of the metacategories of 'religion' and 'ritual'. However, more work across discipline's boundaries is needed to establish more accurate and refined tools for a second-order learning of the logics by which the religious contents of concepts are generated and how they are used in local and post-local contexts. 
Bibliography

\section{Anttonen, Veikko}

1987 Uno Harva ja suomalainen uskontotiede. [Uno Harva and the Science of Religion in Finland]. Helsinki: Finnish Literature Society.

1996a Ihmisen ja maan rajat: 'Pyhä' kulttuurisena kategoriana. [The Making of Corporeal and Territorial Boundaries: The 'Sacred' as a Cultural Category]. Helsinki: Finnish Literature Society.

1996b Rethinking the sacred: The notions of 'human body' and 'territory' in conceptualizing religion. - T. A. Idinopulos \& E. A. Yonan (eds), The Sacred and Its Scholars: Comparative Methodologies for the Study of Primary Religious Data, 36-64. Leiden: E. J. Brill.

1999 Does the sacred make a difference? Category formation in comparative religion. - Tore Ahlbäck (ed.), Approaching Religion, Part I, 9-23. (Scripta Instituti Donneriani, 17:1.) Abo: Donner Institute.

2000a Sacred. - Willi Braun \& Russell T. McCutcheon (eds), Guide to the Study of Religion, 271-282. London: Cassell.

$2000 \mathrm{~b}$ What is it that we call 'religion'? Analyzing the epistemological status of the sacred as a scholarly category. - Armin W. Geertz \& Russell T. McCutcheon (eds), Perspectives on Method in the Study of Religion, 195-206. Leiden: Brill.

2000c The Enigma of the Sacred Pillar: Explaining the Sampo. - Nils G. Holm et at. (eds), Ethnography Is A Heavy Rite. Studies of Comparative Religion in Honor of Juha Pentikäinen, 165-192. (Religionsvetenskapliga Skrifter No 47.) Åbo: Åbo Akademi University.

2002 Identifying the Generative Mechanisms of Religion: The Issue of Origin Revisited. - Ilkka Pyysiäinen \& Veikko Anttonen (eds), Current Approaches in the Cognitive Science of Religion, 14-37. London \& New York: Continuum.

2004 Pathways to Knowledge in Comparative Religion: Clearing Ground for New Conceptual Resources. - Timothy Light \& Brian C. Wilson (eds), Religion as a Human Capacity. A Festschrift in Honor of E. Thomas Lawson, 105-119. Leiden: Brill.

2005a Space, Body, and the Notion of Boundary: A Category-Theoretical Approach to Religion. - Temenos. Nordic Journal of Comparative Religion $41(2), 185-201$.

2005b Harva, Uno (1882-1949). - Lindsay Jones (Editor-in-Chief), The Encyclopedia of Religion, Vol 6. 2nd Edition, 3782-3784. Detroit: Macmillan Reference USA.

\section{Boyer, Pascal}

1994 The Naturalness of Religious Ideas. Berkeley: University of California Press.

2001 Religion Explained: The Evolutionary Origins of Religious Thought._New York: Basic Books.

\section{Capps, Walter $\mathbf{H}$.}

1995 Religious studies: The Making of a Discipline. Minneapolis: Fortress Press. 
Choksy, Jamsheed K.

2003 To Cut Off, Purify, and Make Whole: Historiographical and Ecclesiastical Conceptions of Ritual Space. - Journal of the American Oriental Society 123(1), 21-41.

\section{Colpe, Carsten}

2005 The Sacred and The Profane - Lindsay Jones (Editor-in-Chief), The Encyclopedia of Religion, Vol 12. 2nd Edition, 7964-7978. Detroit: Macmillan Reference USA.

\section{Comstock, W. Richard}

1984 Toward Open Definitions of Religion. Journal of the American Academy of Religion 52, 499-517.

\section{Eliade, Mircea}

1958 Patterns in Comparative Religion. London: Sheed and Word.

1959 The Sacred and the Profane. New York: Harvest Books.

1964 Shamanism: Archaic Techniques of Ecstasy. London: Routledge and Kegan Paul.

1969 The Quest: History and Meaning in Religion. Chicago: University of Chicago Press.

1975 Some Observations on European Witchcraft. - History of Religions 14 (3), 149-172.

1982 Autobiographical Fragment. - Norman J. Girardot \& Mac Linscott Ricketts (eds), Imagination and Meaning. The Scholarly and Literary Worlds of Mircea Eliade, 113-127. New York: Seabury Press.

\section{Guthrie, Stewart}

1995 (1993) Faces in the Clouds: A New Theory of Religion. New York: Oxford University Press.

\section{Harva (Holmberg), Uno}

1922 Der Baum des Lebens. Annales Academiae Scientiarum Fennicae B 16: 3. Helsinki. [Republished as Der Baum des Lebens. Göttingen und Baumkult. Bern: Edition Amalia, 1996.]

1927 Finno-Ugric, Siberian. - John Arnott MacCulloch (ed.), The Mythology of All Races in thirteen volumes. Volume IV. New York: Cooper Square Publishers, Inc.

1938 Die Religiösen Vorstellungen der Altaischen Völker. (FF Communications No 125.) Helsinki: Academia Scientiarum Fennica.

1944 Sampo-sanasta ja vähän muustakin. - Virittäjä 48, 332-341.

Hultkrantz, Åke

1996 A New Look at the World Pillar in Arctic and Sub-Arctic Religions. - Juha Pentikäinen (ed.), Shamanism and Northern Ecology, 31-49. (Religion and Society 36.) Berlin: Mouton de Gruyter. 


\section{Knott, Kim}

2005 The Location of Religion. A Spatial Analysis. London: Equinox.

\section{Malinowski, Bronislaw}

1962 Sex, Culture and Myth. New York: Harcourt, Brace \& World.

\section{Martin, Luther $\mathbf{H}$.}

1996 Introduction: The post-Eliadean study of religion and the new comparativism. - Method and Theory in the Study of Religion 8(1), 1-3.

2003 Cognition, Society and Religion: a new approach to the study of culture. - Culture and Religion 4(2), 207-231.

McCutcheon, Russell T.

2003 The Discipline of Religion: Structure, Meaning, Rhetoric. London: Routledge.

\section{Moore, Robert L.}

1984 Space and Transformation in Human Experience. - Robert L. Moore \& Frank E. Reynolds (eds), Anthropology and the Study of Religion, 126-143. Chicago: Center for the Scientific Study of Religion.

\section{Paden, William E.}

1991 Before 'The Sacred' Became Theological: Rereading The Durkheimian Legacy. - Method E Theory in the Study of Religion 3, 10-23.

1992 Interpreting the Sacred: Ways of Viewing Religion. Boston: Beacon Press.

1994 Religious Worlds: The Comparative Study of Religion. Boston: Beacon Press.

1996 Elements of a new comparativism. - Method and Theory in the Study of Religion 8(1), 5-14.

1999 Sacrality and the worldmaking: New categorial perspective. - Tore Ahlbäck (ed.), Approaching Religion, Part I, 165-180. (Scripta Instituti Donneriani, 17:1.) Åbo: The Donner Institute.

2000 Sacred Order. - Armin W. Geertz \& Russell T. McCutcheon (eds), Perspectives on Method in the Study of Religion, 207-225. Leiden: Brill.

\section{Parkin, David}

1991 Sacred Void: Spatial Images of Work and Ritual among the Giriama of Kenya. Cambridge: Cambridge University Press.

\section{Rappaport, Roy A.}

1999 Ritual and Religion in the Making of Humanity. Cambridge: Cambridge University Press.

\section{Saler, Benson}

2000 Conceptualizing Religion: Immanent Anthropologists, Transcendent Natives, and Unbound Categories. New York: Berghahn. 


\section{Sharpe, Eric J.}

1994 Comparative Religion: A History. La Salle IL: Open Court.

\section{Smith, Jonathan Z.}

1987 To Take Place: Toward Theory in Ritual. Chicago: University of Chicago Press.

2004 Relating Religion: Essays in the Study of Religion. Chicago: University of Chicago Press.

\section{Thomas, Terence}

2004 'The Sacred' as a Viable Concept in the Contemporary Study of Religions. - Steven J. Sutcliffe (ed.), Religion: Empirical Studies, 47-66. Aldershot: Ashgate.

Werblowsky, R. J. Zvi

1989 Nostro Tempore: On Mircea Eliade. - Religion 19, 129-136. 